\title{
Effect of pFSH dose reduction on in vivo embryo production in Dorper ewes
}

\section{Efeito da redução da dose de pFSH na produção in vivo de embriões em ovelhas Dorper}

\author{
João Bosco Loiola Filho'; Alane Pains Oliveira do Monte'; \\ Thais Thatiane dos Santos Souza ${ }^{1}$; Mayara de Souza Miranda ${ }^{1}$; \\ Lívia Correia Magalhães ${ }^{1}$; Celso Henrique Souza Costa Barros²; \\ Ana Arlete de Amorim Silva²; Adriano Oliveira Santos'; \\ Aionne de Souza Leite Guimarães ${ }^{2}$; Jonathan Maia da Silva Costa²; \\ Rodrigo Bonfim Cruz ${ }^{3}$; Mabel Freitas Cordeiro ${ }^{4}$; Edilson Soares Lopes Júnior ${ }^{4 *}$
}

\begin{abstract}
To evaluate the effect of pFSH dose on the in vivo embryo production of Dorper ewes in the semi-arid northeast of Brazil, 40 sheep females were distributed into two groups of 20 animals that received intravaginal CIDR for 14 days, and two days before device removal, they received one of the following treatments: in the FSH200 group, the ewes received $200 \mathrm{mg}$ of pFSH; and in the FSH128 group, the ewes received a total of $128 \mathrm{mg}$ in decreasing doses every $12 \mathrm{~h}$. Beginning $12 \mathrm{~h}$ after the conclusion of the treatments, estrus detection was performed every four hours using two Dorper rams of proven fertility. The ewes were mated at estrus onset and 24 hours later. Seven days after intravaginal device removal, the superovulatory response was evaluated, and embryo collection was performed using the laparotomy method. The recovered flushings were subjected to embryo searches under a stereomicroscope and classified according to their qualities. Analyses of variance (ANOVAs) and LSD tests were used to compare the different parameters. The data expressed as percentages were analysed by chi-square test. The ovulation rate was higher in the FSH200 group, which had $16.3 \pm 0.3$ corpora lutea (CL), than in the FSH128 group, which had $11.3 \pm 0.3 \mathrm{CL}(\mathrm{P}<0.05)$. However, higher fertilization rate $(83.6 \%$ vs. $62.4 \%)$ and higher transferable ( $86.0 \%$ vs. $71.6 \%)$ and freezable (67.9\% vs. $40.8 \%)$ embryo rates were observed in the FSH 128 group compared with the group that received $200 \mathrm{mg}$. Furthermore, no significant differences in the remaining parameters were observed between the experimental groups $(\mathrm{P}>0.05)$, demonstrating that $\mathrm{pFSH}$ dose reduction promoted a greater production of freezable and transferable embryos in Dorper ewes subjected to MOET.
\end{abstract}

Key words: MOET, pFSH, reproduction, sheep, superovulation

\footnotetext{
${ }^{1}$ Discentes, Curso de Pós-Graduação em Ciência Animal, Laboratório de Fisiologia e Biotecnologia de Reprodução Animal, LAFIBRA, Petrolina, PE. Brasil. E-mail: bosco_mev@yahoo.com.br; alanepainsvet@gmail.com; thaisthatiane_souza@hotmail. com; miranda.ms@hotmail.com; liviamagalhaes@yahoo.com.br

${ }^{2}$ Discentes, Curso de Graduação em Medicina Veterinária, Universidade Federal do Vale do São Francisco, UNIVASF, Petrolina, PE. Brasil. E-mail: celso_barrosmv@hotmail.com; anaarleteamorim@hotmail.com; adriano-vet23@hotmail.com; aionneveterinaria@hotmail.com; jonathanmaiacosta@yahoo.com.br

${ }^{3}$ Médico Veterinário, Empresa Baiana de Desenvolvimento Agrícola, EBDA, Juazeiro, BA. Brasil. E-mail: rodvet02@yahoo.com.br

${ }^{4}$ Profs., Universidade Federal do Vale do São Francisco, UNIVASF, Petrolina, PE. Brasil. E-mail: mabel.cordeiro@univasf.edu. br; edilson.lopes@univasf.edu.br

* Author for correspondence
} 


\section{Resumo}

Com o objetivo de avaliar o efeito da redução de pFSH na produção in vivo de embriões de ovelhas da raça Dorper exploradas no semiárido do Nordeste do Brasil, 40 fêmeas ovinas foram distribuídas em dois grupos com 20 animais, os quais receberam um CIDR intravaginal por 14 dias e dois dias antes da remoção do dispositivo receberam um tratamento superovulatório proposto: grupo FSH200 onde as ovelhas receberam $200 \mathrm{mg}$ de pFSH, enquanto o grupo FSH128 totalizou $128 \mathrm{mg}$ em doses decrescentes intervaladas por 12 horas. Doze horas após o final do tratamento, foi realizada a detecção de estro, a cada quatro horas, utilizando dois carneiros Dorper, de fertilidade comprovada. As ovelhas foram cobertas no início do estro e 24 horas depois. Sete dias após a retirada do dispositivo intravaginal, foi realizada a avaliação da resposta superovulatória e a colheita de embriões pelo método de laparotomia. O lavado recuperado foi submetido à procura de embriões em estereomicroscópio e classificados de acordo com sua qualidade. Para comparação dos diversos parâmetros, foi utilizada a Análise de Variância (ANOVA), seguida da realização do teste LSD. Os dados expressos em porcentagem foram submetidos ao Teste de Qui-quadrado. A taxa de ovulação foi superior no grupo FSH200 com 16,3 \pm 0,3 corpos lúteos (CL) quando comparado ao grupo FSH128 com de 11,3 $\pm 0,3 \mathrm{CL}(\mathrm{P}<0,05)$. Entretanto, foi verificada uma maior taxa de fecundação $(83,6 \%$ vs. $62,4 \%)$ e uma maior taxa de embriões transferíveis $(86,0 \%$ vs. $71,6 \%)$ e congeláveis (67,9\% vs. 40,8\%) no grupo FSH 128 quando comparado ao grupo que recebeu $200 \mathrm{mg}$. Além disso, não foi observada qualquer diferença significativa entre os grupos experimentais, para os demais parâmetros avaliados demonstrando que a redução da dose de pFSH promove maior produção de embriões congeláveis e transferíveis em ovinos Dorper submetidos à MOTE.

Palavras-chave: MOTE, ovelhas, pFSH, reprodução, superovulação

\section{Introduction}

There are several factors that can quantitatively and qualitatively influence the success of multiple ovulation and embryo transfer (MOET) (COGNIÉ et al., 2003). These factors can be divided into internal and external factors. Among the internal factors that directly affect embryo donors, the most important are ovarian status, breed, live weight and body condition score (RUBIANES et al., 1997; SPICER, 2001; GONZALEZ-BULNES et al., 2002; AMMOUN et al., 2006; BARTLEWSKI et al., 2008). Among the external factors, superovulatory hormonal treatment is of primary importance (MAGALHÃES et al., 2009).

Two gonadotrophic drugs that are widely used to induce superovulation are equine gonadotropin chorionic (eCG) and follicle-stimulating hormone (FSH) (COGNIÉ et al., 2003). However, FSH from either from swine ( $\mathrm{pFSH})$ or ovine origin $(\mathrm{oFSH})$ is the hormone that is most often commercially used in MOET programs, and it is applied in four to eight decreasing doses every 12 hours for two to four days (D'ALESSANDRO et al., 2005; VEIGA-LOPEZ et al., 2005). Among the commercially available FSH drugs, there are several factors that can influence the ovulation rate and embryo production of ewes, such as the number and interval of the administrations, the FSH/LH proportion, previous hormonal treatments and primarily the dose used (BOSCOS et al., 1997; D'ALESSANDRO et al., 2005; MARTINEZ et al., 2007).

The dose factor is relevant to obtaining homogeneous superovulatory responses (D'ALESSANDRO et al., 1996; BOSCOS et al., 1997; WU et al., 2011). Several studies have reported that large and small FSH doses during superovulatory treatment can cause decreases in transferable embryo numbers (D'ALESSANDRO et al., 1996; BOSCOS et al., 1997). Upon a very large decrease in FSH dose, a decrease in follicular recruitment is observed, and this reduction also decreases the ovulation rate and consequently the number of transferable embryos (BOSCOS et al., 1997). However, when a very large dose is administered, decreases in oocyte fertilization and embryo quality are observed (D'ALESSANDRO et al., 1996). 
Therefore, we suggest that a commercial dose of FSH (200 mg) would have a negative effect and would lead to consequent superovulation of the ovaries. When several follicles are stimulated, physical limitations of the ovary, as the blood supply to individual follicles, deregulation of the normal endocrine mechanisms and excessive production of ovarian steroids, interfere with efficient follicular development or ovulation (KATANYA et al., 2009). Thus, greater numbers of follicles are be stimulated to continue development with high FSH doses, but few follicles are be able to ovulate and suffer luteinizing atresia (D’ALESSANDRO et al., 1996). Additionally, preliminary reports using less than the commercial FSH dose in Dorper ewes are scarce, and it is thus necessary to investigate the cause of the substantial superovulatory variability in terms of hormonal dose. Therefore, the objective of this study was to verify the effect of a reduction of pFSH dose on the ovarian responses and embryo qualities of Dorper ewes.

\section{Material and Methods}

\section{Animal ethics}

All animal protocols used in this study were approved by the Ethics and Deontology Committee for Studies and Research of the Universidade Federal do Vale do São Francisco (Process 27051112/ CEDEP/UNIVASF). Additionally, all studies were conducted according to the guidelines for the ethical use of animals in research.

\section{Period and location of the experiment}

This study was performed from June to July in 2012 during the end of breeding season. The experiment was conducted at the Experimental Station of the Agricultural Development Company of Bahia, in Jaguarari, Northeastern Brazil at $10^{\circ} 15^{\prime} 50$ " S latitude, $40^{\circ} 11^{\prime} 45^{\prime \prime} \mathrm{W}$ longitude and an altitude of $400 \mathrm{~m}$.

\section{Animals}

Forty multiparous and non-lactating Dorper ewes were used as embryo donors. They were selected after ultrasound examinations that permitted the exclusion of all pregnant and sick animals. The embryo donors weighed $47.9 \pm 8.5 \mathrm{~kg}$ (mean \pm SEM) and had a body condition score $(0=$ extremely thin, $5=$ obese) of $2.8 \pm 0.2$ (mean \pm SEM) (MORANDFEHR; HERVIEU, 1999). As breeders, two Dorper rams with proven fertility based on andrologic examinations were used, and the effect of the ram on embryo production was thus avoided.

All animals were subjected to a semi-intensive system of production in which the spent part of the day on preserved Caatinga and received Tifton hay (Cynodon spp.) ad libitum and commercially concentrated maize containing bran and cotton seed supplements in the late afternoon in indoor facilities according body weight and the requirements of the animals in the breeding season (NRC, 1985). The animals had also free access to clean water and mineral salt. The sanity of the experimental animals was maintained using annual vaccinations (against the rabies virus), trimestral worming, periodic cuts of cloven to avoid pododermatitis and guided discards for caseous lymphadenitis. None of the ewes used in the experiment were subjected to any MOET program.

\section{Experimental design and hormonal treatments}

All ewes were subjected to estrus synchronization treatment using intravaginal devices impregnated with $330 \mathrm{mg}$ of progesterone (EASI-BREED $\mathrm{CIDR}^{\circledR}$, Pfizer, Brazil) that were inserted for 14 days.

To evaluate the effect of a reduced $\mathrm{pFSH}$ dose on the superovulatory treatment, the ewes were allocated into the following two groups: a FSH200 group, and a FSH128 group. The FSH200 group (control) received $200 \mathrm{mg}$ of NIH-FSH-P1 (Folltropin-V ${ }^{\circledR}$, Vetrepharm, Canada) divided into six intramuscular 
(i.m.) decreasing doses $(50,5025,25,25$ and 25 $\mathrm{mg}$ ) every 12 hours 48 hours before CIDR removal. The FSH128 group (reduction) was treated with 128 mg of NIH-FSH-P1 (Folltropin-V ${ }^{\circledR}$, Vetrepharm, Canada) that was also divided into six intramuscular decreasing doses $(32,32,16,16,16$ and $16 \mathrm{mg})$ that were administered as in the FSH200 group.

\section{Estrus detection and fertilization}

Beginning $12 \mathrm{~h}$ after CIDR removal, the estrus detections were initiated. For this, a Santa Ines ram was exposed to females for at least 30 minutes each hour for four hours until the last ewe exhibited estrus. Each ewe was considered to be in estrus when the ram tried to mate with it, and it remained immobile (MAULÉON; DAUZIER, 1965). After estrus confirmation, the females were subjected to natural mating at estrus onset and 24 hours later using a Dorper ram with proven fertility.

\section{Evaluation of the ovulatory response}

Prior to embryo collection and five days after mating, feed and water were withheld from the ewes for at least $24 \mathrm{~h}$. On the following day and immediately prior to embryo collection, the ewes were subjected to laparoscopy to visualize the ovulatory response as described by Oldham and Lindsay (1980) regarding the order of estrus onset. For this, the females were subcutaneously (s.c.) injected with lidocaine hydrochloride (2\%, Anestésico Bravet $^{\circledR}$, BRAVET, Brazil) at the location of the puncture used for laparoscopy. After observations of the ovaries, the females were considered to be responsive to superovulatory treatment when they presented five or more corpora lutea in both of ovaries (CL) (BARIL et al., 1995).

\section{Embryo recovery}

After evaluation of ovulatory response, recovery embryo procedure was started and it was performed using laparotomy method and Foley catheter. Immediately before embryo recovery, the abdominal area anterior udders of the embryo donors were shaved and sprayed with a $2 \%$ iodine solution and $70 \%$ alcohol. Subsequent, and anesthetic protocol involving atropine sulphate $1 \%$ (s.c., Sultropin ${ }^{\circledR}$, Sorologic Laboratory, Portugal) as a pre-anesthetic drug $(0.044 \mathrm{mg} / \mathrm{kg})$ was applied. Ten minutes later, xylazine hydrochloride $\left(2 \%\right.$, Dopaser ${ }^{\circledR}$, Laboratórios Calier S/A, Spain) was administered (i.m., 0.22 to $0.3 \mathrm{mg} / \mathrm{kg}$ ), and ten additional minutes later, lidocaine hydrochloride (2\%, Anestésico Bravet $^{\circledR}$, BRAVET, Brazil) was applied via the high epidural route (4.4 to $10.0 \mathrm{mg} / \mathrm{kg}$ ) (BARIL et al., 1995). Next, 6-8 mL of lidocaine hydrochloride (2\%, Anestésico Bravet ${ }^{\circledR}$, BRAVET, Brazil) was applied (s.c.) to the incision line, which was on the alba line and measured from 7 to $15 \mathrm{~cm}$. The reproductive tract was then exposed, and a flushing recovery procedure was performed near each uterine horn using a Foley 10 catheter $\left(\right.$ Solidor $^{\circledR}$, LAMEDID, Brazil). Furthermore, liquid injection was performed near the utero-tubal junction of each uterine horn using a Gelco 18G catheter (Catéter intravenoso $^{\circledR}$, MEDCARE PVT, India). A total of $40 \mathrm{~mL}$ PBS (DMPBS ${ }^{\circledR}$, VITROCELL, Brazil) was injected into each utero-tubal junction and uterine flushing fluid was recovered using a Foley catheter and a 50-mL plastic tube (Tubo de centrifugação ${ }^{\circledR}$, TPP, Switzerland). After the completion of the flushing, a saline solution containing heparin (50 $\mathrm{UI} / \mathrm{mL}$ of sodium heparin) was sprinkled over the reproductive tract to prevent post operatory adherences. The suturing of several tissue planes was performed according to a simple standard protocol in three planes.

\section{Evaluation of the recovered embryos}

The flushing was placed into plastic petri plates and subjected examination of the embryos with a stereomicroscope (SMZ 645 ${ }^{\circledR}$, Nikon, Japan) at a magnification of 40 to $70 \mathrm{X}$. Evaluations of 
the structural characteristics, including the stage of embryonic development and quality, were performed following the morphologic criteria of the International Embryo Transfer Society (ROBERTSON; NELSON, 2010). Immediately after recovery, the embryos were evaluated and classified as Codes I (excellent or good), II (regular), III (poor) or IV (dead or degenerate).

\section{Statistical analyses}

The overall number of corpora lutea, number of recovered embryos (NEREC), number of ewes that exhibited corpora lutea in regression and the number of persistent follicles in both ovaries were quantified. The number of structures that were not fertilized (ENF) was calculated as the sum of the number of oocytes, the number of empty zona pellucida and the number of freezable (NECONG: Codes I and II) and transferable embryos (Codes I, II and III). The statistical analyses were conducted using the SPSS software (IBM SPSS, version 19.0, 2010, USA). The efficiency of embryo recovery was calculated using the following formula: TRE $=[(\mathrm{NEREC}+\mathrm{ENF}) / \mathrm{CL}] \times 100$. The fertilization and the freezable embryo rates were calculated using the formulas $\mathrm{TF}=[\mathrm{NEREC} / \mathrm{ENF}] \mathrm{x} 100$, $\mathrm{TEC}=[\mathrm{NECONG} /$ recovered structures $] \times 100$, and TETRANF $=$ NETRANF/recovered structures.

Analysis of variance (ANOVA) was used to verify the effect of the pFSH dose. The ENF data were analysed by Fisher's test (LSD) to verify the differences between the means. Regarding the parameters of ovulation rate, embryo recovery rate, fertilization rate and transferable and freezable embryo rates, the differences were evaluated using chi-square tests. All data were analysed using the statistical software SPSS (IBM SPSS, version 19.0, 2010, USA).

\section{Results and Discussion}

Regarding the estrus response, the large majority of the animals exhibited estrus (90\% in the FSH128 group and $100 \%$ in the FSH200 group) at only 16.6 $\pm 0.66 \mathrm{~h}$ after the completion of the progesterone treatment (Table 1). The estrus observed in the Dorper embryo donors occurred earlier than the observations reported by Forcada et al. (2011) in Ojalada Soriana ewes and by Folch et al. (2001) in the Aragonesa sheep breed. These contrasts can be explained by the differences between the drugs that were used for estrus synchronization because those authors used intravaginal sponges impregnated with progestagen, whereas we used devices containing progesterone. Progestagens are metabolized more slowly than progesterone, leading to the late unblocking of the hypothalamic-pituitary axis and consequently to the delay of estrus onset in animals that are treated with progestagens (FLYNN et al., 2000; URIBE-VELASQUEZ et al., 2008).

Table 1. Estrus and ovarian responses of the Dorper ewes after superovulatory treatment with 128 mg (FSH128 group) or $200 \mathrm{mg}$ of pFSH (FSH200 group).

\begin{tabular}{lcc}
\hline & \multicolumn{2}{c}{ Groups } \\
\cline { 2 - 3 } & FSH128 & FSH200 \\
\hline Number of ewes in estrus (\%) & $18 / 20(90 \%)$ & $20 / 20(100 \%)$ \\
Estrus onset (h) & $17.6 \pm 0.1^{\mathrm{a}}$ & $15.6 \pm 0.1^{\mathrm{b}}$ \\
Number of superovulating ewes(\%) & $18 / 20(90 \%)$ & $19 / 20(95 \%)$ \\
Number of corpora lutea (CL) & $11.3 \pm 0.3^{\mathbf{b}}$ & $16.3 \pm 0.3^{\mathrm{a}}$ \\
Number of ewes with CL in regression & $3 / 20(15 \%)$ & $2 / 20(10 \%)$ \\
Number of persistent follicles & $0.5 \pm 0.2$ & $0.6 \pm 0.2$ \\
\hline
\end{tabular}

a,b The values with small letters within the lines indicate significant differences $(\mathrm{P}<0.05)$. 
Furthermore, the group treated with $200 \mathrm{mg}$ of pFSH (FSH200) exhibited estrus earlier than did the FSH128 group $(\mathrm{P}<0.05)$ (Table 1$)$. This result was expected because the animals from the FSH200 group received a higher dose of pFSH that consequently stimulated the follicular secretion of $17 \beta$-estradiol, which is the hormone that promotes estrus behaviour (BARTLEWSKI et al., 2008; MAGALHÃES et al., 2009).

This parameter is so important to multiple ovulation and embryo transfer programs (MOETs) primarily when it is associated with artificial insemination(AI) because the LH surge and ovulation are associated with estrus onset (CAMPBELL et al., 1999); thus, it can be considered indicative of the performance of AI. According to Baril et al. (1993), early estrus onset results in oocytes that are appropriate for fertilization because later estrus is associated with lower quality.

Regarding the superovulatory response, the number of ewes that responded to hormonal treatment with pFSH fluctuated from 90 to $95 \%$ and no significant difference was observed between the experimental groups ( $\mathrm{P}>0.05$, Table 1$)$. In general, the number (mean \pm SEM) of corpora lutea (CL) was $13.85 \pm 1.42$, and the FSH128 group exhibited a lower number of corpora lutea than the FSH200 group ( $\mathrm{P}<0.05$, Table 1). Additionally, low numbers (mean $\pm \mathrm{SEM}$ ) of pale corpora lutea in regression $(0.75 \pm 0.52)$ and persistent follicles $(0.55 \pm 0.20)$ were observed, and no significant difference was observed between the groups in either of these parameters $(\mathrm{P}>0.05)$ (Table 1$)$. These results are similar to those observed by D'Alessandro et al. (2005) and greater than those observed by Folch et al. (2001).

The percentages of females that responded to the superovulatory treatment in both of the experimental groups in the present study indicated that the reduction of the $\mathrm{pFSH}$ dose did not influence this parameter (Table 1). However, the number of corpora lutea in the animals of the FSH200 group was higher than that observed in the FSH128 group $(\mathrm{P}<0.05)$, which demonstrated that the reduction of pFSH dose decreased the number of corpora lutea (Table 1). A similar result was observed by Boscos et al. (1997) when they reduced the pFSH dose from 160 to $120 \mathrm{mg}$ using and applied these doses over six decreasing administrations. However, more recently, a reduction in the number of corpora lutea was not observed when the pFSH dose was decreased from $150 \mathrm{mg}$ to $120 \mathrm{mg}$ with these doses divided into six and three administrations, respectively (WU et al., 2011). This result can be explained by the strong dependence of small antral follicles in FSH at recruitment time (GONZALEZ-BULNES et al., 2002; MAGALHÃES et al., 2009). When the initial administrations of FSH are high, although the global dose of the superovulatory treatment is reduced, the recruitment and growth of several follicles occurs, and the ovulation rate is consequently preserved. Therefore, the reduction in ovulation rate observed at present study can be associated to reduction of pFSH doses of initial administrations.

Another significant factor that influences MOET is the quality of the ovulations and corpora lutea that gain the ability to produce progesterone at concentrations higher than $1.0 \mathrm{ng} / \mathrm{mL}$, which maintains embryo viability and development (SAHARREA et al., 1998). Corpus luteum quality can be observed primarily based on its colour because a pale corpus luteum is associated with a low luteal structure quality. Superovulation protocols using equine chorionic gonadotropin (eCG) are usually characterized by the presence of premature regression of the corpora lutea (PRCL), which is a consequence of the early secretion of prostaglandin $\mathrm{F}_{2 \alpha}$ from the persistent follicles and endometrial glands and high plasma levels of estradiol (BATTYE et al., 1988). A low number of CLs of poor quality and persistent follicles were observed. Menchaca et al. (2009) verified that the use of eCG associated with the last administration of $\mathrm{pFSH}$ promotes reductions in the number of embryos and fertilization rate due to reduced 
ovulation quality. Therefore, it is well established that the use of eCG with the last administration of $\mathrm{pFSH}$ in a superovulatory treatment prejudices embryo production.

The superiority of the number of ovulations of the animals treated with $200 \mathrm{mg}$ of $\mathrm{pFSH}$ reflected the increase in the number of recovered structures $(\mathrm{P}<0.05)$. Thus, there was a reduction of approximately three recovered structures from the animals that received $128 \mathrm{mg}$ of pFSH (Table 2). Boscos et al. (1997) observed a similar reduction when they reduced the pFSH dose administered to Chio ewes.

Table 2. Numbers (mean \pm SEM) of recovered structures and embryos, numbers (mean \pm SEM) of transferable and freezable embryos and embryo recovery, fertilization, transferable and freezable embryo rates (\%) of the Dorper ewes following superovulatory treatment with $128 \mathrm{mg}$ (FSH128 group) or $200 \mathrm{mg}$ of pFSH (FSH200 group).

\begin{tabular}{lccc}
\hline & \multicolumn{2}{c}{ Groups } & \multirow{2}{*}{ P } \\
\cline { 2 - 3 } & FSH128 & FSH200 & \\
\cline { 2 - 3 } Number of recovered structures* $_{\text {Embryo recovery rate** }}^{*}$ & $7.1 \pm 0.8^{\mathrm{b}}$ & $9.8 \pm 1.0^{\mathrm{a}}$ & 0.75 \\
Number of non-fertilized structures & $56.4 \%(128 / 227)$ & $58.1 \%(186 / 320)$ & 0.045 \\
Number of recovered embryos & $1.1 \pm 0.7^{\mathrm{b}}$ & $3.5 \pm 0.7^{\mathrm{a}}$ & 0.708 \\
Fertilization rate*** & $5.9 \pm 0.8$ & $5.3 \pm 0.8$ & $<0.001$ \\
Number of transferable embryos & $83.6 \%(107 / 128)^{\mathrm{a}}$ & $62.4 \%(116 / 186)^{\mathbf{b}}$ & \\
Transferable embryos rate $* * * *$ & $5.1 \pm 0.7$ & $4.4 \pm 0.7$ & $<0.001$ \\
\hline
\end{tabular}

a, b The values with small letters within the lines indicate significant differences $(\mathrm{P}<0.05)$ * (Number of embryos + number of nonfertilized structures); $* *$ (Number of recovered structures / number of corpora lutea) x 100; *** (Number of embryos / number of recovered structures ) x 100; **** (Number of embryos with codes I, II and III / number of recovered structures) x 100; $* * * * *$ (Number of embryos with codes I and II / number of recovered structures) x 100 .

Regarding the numbers of recovered structures, the FSH200 group exceeded the $(\mathrm{P}<0.05)$ FSH128 group, although the embryo recovery rates observed in the experimental groups were similar $(\mathrm{P}>0.05)$. Additionally, the fertilization rate and the rates of transferable and freezable embryos in the FSH128 group were higher than those observed in the FSH200 group $(\mathrm{P}<0.05)$. Furthermore, no significant differences were observed between the experimental groups regarding the remaining parameters $(\mathrm{P}>0.05$, Table 2$)$.

These results were lower than those observed by $\mathrm{Wu}$ et al. (2011) who observed obtained approximately ten embryos following the use of 150 or $120 \mathrm{mg}$ of $\mathrm{pFSH}$. However, Bartlewski et al. (2008) obtained only 4.1 embryos using $250 \mathrm{mg}$ of $\mathrm{pFSH}$, which demonstrated that high pFSH doses and estradiol levels prejudice embryo production (KATANYA et al., 2009). This report was corroborated by the present study because some of the animals in both groups exhibited uteri with hyperemic aspects and that required laborious manipulation that hindered embryo collection and thus reduced the embryo recovery rate at the time of the laparotomies.

Among the several factors that influence embryo production (i.e., follicular status, FSH endogenous level, season and breed) (AMMOUN et al., 2006; BARTLEWSKI et al., 2008; BETTENCOURT et al., 2008; BARTLEWSKI et al., 2009; MENCHACA et al., 2010), the dose of gonadotropin used deserves special attention. In the present study, a reduction of the FSH dose promoted a decrease in the nonfertilized structures. These results verify that the use of high FSH doses does not elicit great benefits in terms of either economic aspects or individual 
hypothalamic-pituitary axis responses. Therefore, the rational use of pFSH is necessary mainly when it is associated with controlling follicular dynamics to avoid the presence of dominant follicles that hamper small follicle recruitment (MENCHACA et al., 2010).

The most important result of a MOET program is the number of transferable or freezable embryos that can be subjected to embryo transfer or cryopreservation. The present study demonstrated that a reduction in $\mathrm{pFSH}$ increased the both the transferable and freezable embryo rates. Therefore, a reduction of $\mathrm{pFSH}$ dose improved the cost-benefit relationship of this biotechnology (MOET) because $\mathrm{pFSH}$ exerts a great influence on in vivo embryo production costs in addition to promoting higher embryo quality because transferable and freezable embryos exhibit the highest levels of quality concerning their morphological characteristics.

\section{Conclusions}

In conclusion, the pFSH dose influences the ovarian response and embryo quality in Dorper ewes that are subjected to in vivo embryo production. The lowest pFSH dose prejudiced the ovulation rate and the number of recovered structures. However, this reduction of the ovulation rate did not affect the production of transferable (Codes I, II and III) or freezable (Codes I and II) embryos, which demonstrated that reductions in $\mathrm{pFSH}$ are viable because they improve the overall MOET program. Additionally studies concerning the effect of $\mathrm{pFSH}$ reductions in other sheep breed and during different periods are necessary because the production of endogenous FSH can interfere with the overall process.

\section{Acknowledgements}

The authors are grateful to Doctor Vicente Freitas and the Laboratory of Physiology and Control of Reproduction for the generous supply of the laparoscopic system used for the ovarian evaluations. The authors also thank the Foundation for Science and Technology of the State of Pernambuco (FACEPE) for financial support of the experiment and the Experimental Station of Agricultural Development Company of Bahia (EBDA) for providing the animals and facilities for the experiment. Additional acknowledgments are necessary to Doctor Daniel Maia Nogueira for the statistical analysis procedures.

\section{References}

AMMOUN, I.; ENCINAS, T.; VEIGA-LOPEZ, A.; ROS, J. M.; CONTRERAS, I.; GONZALEZ-ANOVER, P.; COCERO, M. J.; MCNEILLY, A. S.; GONZALEZBULNES, A. Effects of breed on kinetics of ovine FSH and ovarian response in superovulated sheep. Theriogenology, Stoneham, v. 66, n. 4, p. 896-905, 2006.

BARIL, G.; BREBION, P.; CHESNÉ, P. Manual de formación práctica para el trasplante de embriones en ovejas y cabras. Roma: FAO, 1995. $182 \mathrm{p}$.

BARIL, G.; REMY, B.; LEBOEUF, B.; BECKERS, J. F.; SAUMANDE, J. Synchronization of estrus in goats: the relationship between eCG binding plasma, time of occurrence of estrus and fertility following artificial insemination. Theriogenology, Stoneham, v. 45, n. 3, p. 1553-1559, 1993.

BARTLEWSKI, P. M.; ALEXANDER, B. D.; KING, W. A. Ovarian and endocrine determinants of superovulatory responses in anestrous ewes. Small Ruminant Research, Amsterdam, v. 75, n. 2, p. 210-216, 2008.

BARTLEWSKI, P. M.; FUERST, K. J.; ALEXANDER, B. D.; KING, W. A. Systemic concentrations of endogenous and exogenous FSH in anoestrous ewes superstimulated with Folltropin-V, short communication. Reproduction in Domestic Animals, Berlin, v. 44, n. 2, p. 353-358, 2009.

BATTYE, K. M.; FAIRCLOUGH, R. J.; CAMERON, A. W. N.; TROUNSON, A. O. Evidence for prostaglandin involvement in early luteal regression of the superovulated nanny goat. (Capra hircus). Journal Reproduction and Fertility, Cambridge, v. 84, n. 2, p. 425-430, 1988.

BETTENCOURT, E. M.; BETTENCOURT, C. M.; CHAGAS E SILVA, J.; FERREIRA, P.; MANITO, C. I.; MATOS, C. M.; ROMÃO, R. J.; ROCHA, A. Effect of season and gonadotrophin preparation on superovulatory response and embryo quality in Portuguese Black 
Merinos. Small Ruminant Research, Amsterdam, v. 74, n. 1, p. 134-139, 2008.

BOSCOS, C.; VAINAS, E.; KOUSKOURA, T. H.; SAMARTZI, F.; VAFIADIS, D.; DELLIS, S. Superovulatory response of chios and friesian ewes to two FSH-P dose levels. Reproduction in Domestic Animals, Berlin, v. 32, n. 4, p. 195-198, 1997.

CAMPBELL, B. K.; DOBSON, H.; BAIRD, D. T.; SCARAMUZZI, R. J. Examination of the relative role of FSH and LH in the mechanism of ovulatory follicle selection in sheep. Journal of Reproduction and Fertility, Cambridge, v. 117, n. 2, p. 355-367, 1999.

COGNIÉ, Y.; BARIL, G.; POULIN, N.; MERMILLOD, P. Current status of embryo technologies in sheep and goats. Theriogenology, Cambridge, v. 59, n. 4, p. 171188, 2003.

D'ALESSANDRO, A.; MARTEMUCCI, G.; TAIBI, L. How the FSH/LH ratio and dose numbers in the p-FSH administration treatment regimen, and insemination schedule affect superovulatory response in ewes. Theriogenology, Cambridge, v. 63, n. 6, p. 1764-1774, 2005.

D'ALESSANDRO, A.; MARTEMUCCI, G.; TOTEDA, F.; GAMBACORTA, M.; MANCHISI, A. Superovulation and embryo production in ewes using a commercial p-FSH. Small Ruminant Research, Amsterdam, v. 19, n. 3, p. 255-261, 1996.

FLYNN, J. D.; DUFFY, P.; BOLAND, M. P.; EVAN, A. C. O. Progestagen synchronisation in the absence of a corpus luteum results in the ovulation of a persistent follicle in cyclic ewe lambs. Animal Reproduction Science, Manchester, v. 62, n. 4, p. 285-296, 2000.

FOLCH, J.; RAMON, J. P.; COCERO, M. J.; ALABART, J. L.; BECKERS, J. F. Exogenous growth hormone improves the number of transferable embryos in superovulated ewes. Theriogenology, Cambridge, v. 55, n. 9, p. 1777-1765, 2001.

FORCADA, F.; AMER-MEZIANE, M.; ABECIA, J. A.; MAUREL, M. C.; CEBRIÁN-PÉREZ, J. A.; MUIÑOBLANCO, T.; ASENJO, B.; VÁZQUEZ, M. I.; CASAO, A. Repeated superovulation using a simplified FSH/ eCG treatment for in vivo embryo production in sheep. Theriogenology, Cambridge, v. 75, n. 4, p. 769-776, 2011.

GONZALEZ-BULNES, A.; GARCIA-GARCIA, R. M.; SANTIAGO-MORENO, J.; LOPEZ-SEBASTIAN, A.; COCERO, M. J.; BAIRD, D. T. Patterns of follicular growth in superovulated sheep and influence on endocrine and ovarian response. Reproduction in Domestic Animals, Berlin, v. 37, n. 6, p. 357-361, 2002.
KATANYA, J. F.; PAWEL, M. B.; KING, W. A. Relationship between circulating concentrations of ovarian steroids and the superovulatory responses in anestrous ewes following a multiple-dose $\mathrm{pFSH}$ regimen. Small Ruminant Research, Amsterdam, v. 82, n. 2, p. 144-148, 2009.

IBM SPSS Statistics for Windows, Version 19.0 (Released 2010). rmonk, NY, USA: IBM Corp., 2010.

MAGALHÃES, D. M.; FERNANDES, D. D.; ARAUJO, V. R.; ALMEIDA, A. P.; MATOS, M. H. T.; FIGUEIREDO, J. R. Papel do Hormônio Folículo Estimulante na foliculogênese in vivo e in vitro. Revista Brasileira de Reprodução Animal, Belo Horizonte, v. 33, n. 4, p. 171-182, 2009.

MARTINEZ, J. J.; IZAGUIRRE, F.; SÁNCHEZ, L. Comportamiento reproductivo de ovejas Barbados Barriga Negra sincronizadas con MPA y diferentes tiempos de aplicación de eCG durante la época de baja fertilidad. Revista Científica, Porto Alegre, v. 17, n. 1, p. 47-52, 2007.

MAULÉON, P.; DAUZIER, K. Variations de durée de l'anoestrus de lactation chez les brebis de race Ilede-France. Annales de Biologie Animale Biochimich Biophysic, Nouzilly, v. 5, n. 1, p. 131, 1965.

MENCHACA, A.; VILARIÑO, M.; CRISPO, M.; CASTRO, T.; RUBIANES, E. New approaches to superovulation and embryo transfer in small ruminants. Reproduction, Fertility and Development, East Melbourne, v. 22, n. 1, p. 113-118, 2010.

MENCHACA, A.; VILARIÑO, M.; PINCZAK, A.; KMAID, S.; SALDANÃ, J. M. Progesterone treatment, FSH plus eCG, GnRH administration, and day 0 protocol for MOET programs in sheep. Theriogenology, Cambridge, v. 72, n. 4, p. 477-483, 2009.

MORAND-FEHR, P.; HERVIEU, J. Apprécier l'comer Corporel des Chèvres: interet et método. Réussir La Chevre, Nouzilly, v. 231, p. 22-34, 1999.

NATIONAL RESEARCH COUNCIL- NRC. Nutrient requirements of sheep. Nutrient requirements of domestic animals. Washington: National Academy Press, 1985. $109 \mathrm{p}$.

OLDHAM, C. M.; LINDSAY, D. R. Laparoscopy in the ewe: a photographic record of the ovarian activity of ewes experiencing normal or abnormal oestrous cycles. Animal Reproduction Science, Manchester, v. 3, n. 2, p. 119-124, 1980.

ROBERTSON, I.; NELSON, R. Certification and identification of embryos. In: STRINGFELLOW, D. A.; GIVENS, M. D. (Ed.). Proceedings of guide of 
international embryo transfer society. IETS: Champaign, Illinois, USA, 2010. p. 86-105.

RUBIANES, E.; UNGERFELD, R.; VINOLES, C.; RIVERO, A.; ADAMS, G. P. Ovarian response to gonadotropin treatment initiated relative to wave emergence in ultrasonographically monitored ewes. Theriogenology, Cambridge, v. 47, n. 8, p. 1479-1488, 1997.

SAHARREA, A.; VALENCIA, J.; BALCÁZAR, A.; MEDJA, O.; CERBÓN, J. L.; CABALLERO, V.;ZARCO, L. Premature luteal regression in goats superovulated with PMSG: effect of hCG or GnRH administration during the early luteal phase. Theriogenology, Cambridge, v. 50, n. 7, p. 1039-1052, 1998.

SPICER, L. J. Leptin: a possible metabolic signal affecting reproduction. Domestic Animal Endocrinology, Auburn, v. 21, n. 4, p. 251-270, 2001.
URIBE-VELÁSQUEZ, L. F.; OBA, E.; SOUZA, M. I. L. Efeitos da progesterona exógena sobre o desenvolvimento folicular em ovelhas. Arquivo Brasileiro de Medicina Veterinária e Zootecnia, Belo Horizonte, v. 60, n. 1, p. 58-65, 2008.

VEIGA-LOPEZ, A.; GONZALEZ-BULNES, A.; GARCIA-GARCIA， R. M.; DOMINGUEZ， V.; COCERO, M. J. The effects of previous ovarian status on ovulation rate and early embryo development in response to superovulatory FSH treatments in sheep. Theriogenology, Cambridge, v. 63, n. 7, p. 1973-1983, 2005.

WU, W.; YANG, M.; GONG, P.; WANG, F.; TIAN, Y.; XU, X.; FU, X.; TIAN, K.; GUO, Z. Effect of two follicle stimulating hormone (FSH) preparations and simplified superovulatory treatments on superovulatory response in Xinji fine-wool sheep. African Journal of Biotechnology, Nairob, v. 10, n. 70, p. 15834-15837, 2011. 